\title{
PEMBERIAN INFORMASI TERHADAP PENGETAHUAN KELUARGA TENTANG BINA KELUARGA REMAJA
}

\author{
Arum Dwi Anjani1), Dede Lusitania2) \\ ${ }^{1}$ The Study Program of Midwifery Faculty of Medicine Batam University \\ Email: arum.dwianiani05@univbatam.ac.id \\ ${ }^{2}$ The Study Program of Midwifery Faculty of Medicine Batam University \\ Email: lusitania0811@gmail.com
}

\begin{abstract}
In Indonesia the amount of BKR group is 17.073 groups and the number of BKR member is 183.061 .627 member, meanwhile the amount of active member only 541.704 member. One of the provinces that participate on BKR group that have the most and active member found at central java with BKR group amount 4434 groups and 2177 active members, also two provinces that don't have BKR group are north kalimantan and west papua, meanwhile in papua province the amount of BKR group is 16 groups, however none of the group is active.

This research designed pretest-posttest one group design. The study was conducted in Kampung Tua Dapur 12 district from February to August 2017. The total of the population investigated was 147 families with adolescents aged 10 to 24 years in which later selected 147 respondents using total sampling technique. The research instruments used to gather the data was questionnaire. Further, the data gathered from the questionnaires was tested by T-test analysis.

The result of study displays the mean of family knowledge before the information provision is $18.18 \pm 4.88$ and after is $22.50 \pm 4.46$ from total score of 30 . It is noted an elevation of 4.32 based on the before and after information provision and is strengthen by the result of T-Test $p$ value of $0.000(p<0.05)$.

Conclusion There is an effect of giving information to knowledge of family that have adolescent about build a teenage family.
\end{abstract}

Keywords : Information Assistance On Family Knowledge

\section{ABSTRAK}

Di Indonesia jumlah kelompok BKR sejumlah 17.073 kelompok dan jumlah anggota BKR sebanyak 183.061.627 anggota, sedangkan jumlah anggota BKR yang aktif hanya 541.704 anggota. Salah satu provinsi yang ikut serta dalam kelompok BKR yang memiliki kelompok BKR terbanyak dan aktif terdapat di provinsi Jawa Tengah dengan jumlah kelompok BKR 4434 kelompok dan yang aktif sejumlah 2177 anggota, dan terdapat dua provinsi yang tidak memiliki kelompok BKR yaitu provinsi Kalimantan Utara dan Papua Barat, sedangkan di provinsi Papua jumlah kelompok BKR sebanyak 16 kelompok, namun tidak ada satupun kelompok yang aktif dalam kelompok BKR tersebut.Tujuan penelitian ini diketahui Pengaruh Pemberian Informasi Terhadap Pengetahuan Keluarga Tentang Bina Keluarga Remaja.

Penelitian menggunakan rancangan Quasi eksperimental pretest-posttest one group design dilakukan di Kampung Tua Dapur 12 pada bulan Februari - Agustus 2017 dengan jumlah populasi 147 keluarga yang memiliki remaja usia 10-24 tahun dan sampel sebanyak 147 responden, pengambilan sampel menggunakan Total sampling dengan menggunakan kuesioner. Analisis data menggunakan teknik analisis T-test.

Penelitian rerata pengetahuan keluarga yang memiliki remaja sebelum diberikan informasi 18,18 \pm 4,88 dan sesudah diberikan informasi 22,50 \pm 4,46 dari total skor 30 mengalami peningkatan 4,32 hasil uji T-Test $p$ $0,000(p<0,05)$. Kesimpulannya ada pengaruh pemberian informasi terhadap pengetahuan keluarga yang memiliki remaja tentang Bina Keluarga Remaja

Kata Kunci : Informasi, Pengetahuan, Keluarga

\section{PENDAHULUAN}

Menurut World Health Organization (WHO), remaja adalah penduduk dalam rentang usia 10-19 tahun, menurut peraturan Menteri Kesehatan RI Nomor 25 tahun 2014, remaja adalah penduduk dalam rentang usia 10-18 tahun dan menurut 
Badan Kependudukan dan Keluarga Berencana Nasional (BKKBN) rentang usia remaja adalah usia 10-24 tahun dan belum menikah. Jumlah kelompok usia 10-19 tahun di Indonesia menurut Sensus Penduduk tahun 2010 sebanyak 43,5 juta atau sekitar 18\% dari jumlah penduduk. Di dunia diperkirakan kelompok remaja berjumlah 1,2 milyar atau $18 \%$ dari jumlah penduduk dunia (WHO, 2013)

Remaja dan permasalahannya menjadi isu penting saat ini. Jumlah yang besar, yaitu sekitar 64 juta atau $27,6 \%$ dari jumlah penduduk Indonesia mengakibatkan remaja memerlukan perhatian besar dalam pembinaannya. Remaja sangat rentan terhadap resiko Triad Kesehatan Reproduksi Remaja (KRR), (Seksualitas, Narkotika Psikotropika dan Zat Adiktif (NAPZA), (HIVIAIDS). Perilaku seksual yang tidak sehat dikalangan remaja, khususnya remaja yang belum menikah cenderung meningkat. Data dari Departemen Kesehatan tahun 2009 menunjukkan bahwa 35,9\% remaja di tempat kota besar (Medan, Jakarta Pusat, Bandung dan Surabaya) mempunyai teman yang sudah pernah melakukan hubungan seks pranikah (BKKBN, 2013)

Permasalahan remaja merupakan permasalahan yang sangat komplek mulai dari jumlahnya yang cukup besar hingga permasalahan TRIAD KRR (Kesehatan Reproduksi Remaja). Berdasarkan proyeksi penduduk pada tahun 2015 menunjukan bahwa jumlah remaja (usia 10-24 tahun) Indonesia mencapai lebih dari 66,0 juta atau $25 \%$ dari jumlah penduduk Indonesia 255 juta(BAPPENAS, BPS, 2013)

BNN mencatat hingga akhir 2015, pengguna narkotika di Provinsi Kepulauan Riau (Kepri) sebanyak 41.767 jiwa atau mencapai 2,94 persen dari 1,5 juta penduduk setempat. Berdasarkan hasil survei yang dilakukan BNN Pusat dengan Universitas Indonesia (UI) tahun 2017, Provinsi Kepulauan Riau (Kepri) menempati peringkat keempat sebagai daerah rawan peredaran gelap narkoba dan penyalahgunaan narkoba di Indonesia. Berdasarkan hasil survei Provinsi Kepri, khususnya Batam berada di peringkat keempat peredaran narkoba di Indonesia. Dari aspek geografis, Kepri memiliki kerentanan karena wilayahnya yang terdiri dari pulau-pulau dan berbatasan dengan Singapura dan Malaysia, "ujar Kepala BNN Kepulauan Riau (Brigjend Pol Nikson Manurung, 2017)".

Permasalahan remaja seperti diuraikan diatas sangat kompleks dan mengkhawatirkan. Permasalahan tersebut akan mengurangi kesempatan remaja untuk mempraktekkan prilaku hidup sehat, serta mengganggu perencanaan kehidupan di masa yang akan datang. Melalui program pengembangan Generasi Berencana
(GenRe), dalam hal ini BKKBN sebagai salah satu instansi pemerintah yang merespon permasalahan tersebut (BKKBN, 2013).

Program GenRe dilaksanakan melalui pendekatan dari dua sisi, yaitu pendekatan kepada remaja itu sendiri dan pendekatan kepada keluarga yang mempunyai remaja. Pendekatan kepada remaja dilakukan melalui pengembangan Pusat Informasi dan Konseling Remaja/Mahasiswa (PIK $\mathrm{R} / \mathrm{M}$ ), sedangkan pendekatan kepada keluarga dilakukan melalui pengembangan kelompok Bina Keluarga Remaja (BKR). Pendekatan kepada remaja dan keluarga didasari oleh hasil Survey Demografi Kependudukan Indonesia (SDKI, 2003), yang menunjukkan bahwa remaja lebih menyukai untuk menceritakan masalahnya kepada teman sebaya $(71 \%)$, dan kepada orang tua $(31 \%)$. Meskipun remaja lebih memilih menceritakan permasalahan kepada kepada teman sebayanya, namun peran keluarga tetap penting karena remaja masih dalam pembinaan dan pengasuhan orang tua, dimana pembentukan karakter remaja dimulai dari keluarga (BKKBN, 2013).

Dari berbagai data menunjukkan bahwa keluarga melalui pola asuh orang tua, telah diidentifikasi sebagai pengaruh yang sangat penting dalam pembentukan karakter remaja, termasuk yang berkaitan dengan kesehatan reproduksi. Proses pola asuh orang tua meliputi kedekatan orang tua dengan remaja, pengawasan orang tua, dan komunikasi orang tua dengan remaja. Melalui komunikasi, orang tua hendaknya menjadi sumber informasi dan pendidik utama tentang kesehatan reproduksi remaja, juga tentang perencanaan kehidupan remaja dimasa yang akan datang. Namun demikian, orang tua sering menghadapi kendala dalam berkomunikasi kepada remajanya, begitupun sebaliknya (BKKBN, 2013).

Program Bina Keluarga Remaja ini merupakan salah satu program yang dikembangkan oleh Badan Kependudukan Keluarga Berencana Nasional (BKKBN) dalam upaya menciptakan ketahanan keluarga dan mewujudkan peningkatan kualitas remaja sebagai implementasi UndangUndang Nomor 52 Tahun 2009, tentang Perkembangan Kependudukan dan Pembangunan Keluarga dimana dalam pengelolaan programnya didasarkan pada peraturan Kepala BKKBN NOMOR 109/PERF2/2012. Program Bina Keluarga Remaja (BKR) merupakan salah satu kegiatan yang sangat strategis dalam mengupayakan terwujudnya Sumber Daya Manusia potensial melalui upaya meningkatkan terwujudnya pengetahuan dan keterampilan keluarga dalam mengasuh dan membina tumbuh kembang remaja melalui peran 
orang tua dalam keluarga (BKKBN, 2013).Sehubungan dengan hal tersebut, pengembangan kelompok Bina Keluarga Remaja (BKR) dapat membantu orang tua dalam memahami remaja, permasalahan remaja, dan cara berkomunikasi dengan remaja. Melalui kelompok BKR setiap keluarga yang memiliki remaja dapat saling bertukar informasi dan berdiskusi bersama tentang hal-hal yang berkaitan dengan remaja, meliputi Kebijakan Program GenRe, Penanaman Nilai-Nilai Moral Melalui 8 Fungsi Keluarga, Pendewasaan Usia Perkawinan, Seksualitias, NAPZA, HIVIAIDS, Keterampilan Hidup, Ketahanan Keluarga Berwawasan Gender, Komunikasi Efektif Orangtua terhadap Remaja, Peran Orangtua Dalam Pembinaan Tumbuh Kembang Remaja, dan Pemenuhan Gizi Remaja (BKKBN, 2013).

Kelompok Bina Keluarga Remaja ini telah dikembangkan di seluruh Provinsi Indonesia, dan sampai dengan Desember 2011 telah berkembang sebanyak 33.779 kelompok. Jumlah yang banyak tersebut perlu dikelola dan dibina secara berkesinambungan, sehubungan dengan hal ini maka diperlukan suatu pedoman yang menjadi acuan atau pegangan bagi pengelola Program GenRe di semua tingkatan dan Pengelola BKR/kader (BKKBN, 2013).

Di Indonesia jumlah kelompok BKR sejumlah 17.073 kelompok dan jumlah anggota BKR sebanyak 183.061.627 anggota, sedangkan jumlah anggota BKR yang aktif hanya 541.704 anggota. Salah satu provinsi yang ikut serta dalam kelompok BKR yang memiliki kelompok BKR terbanyak dan aktif terdapat di provinsi Jawa Tengah dengan jumlah kelompok BKR 4434 kelompok dan yang aktif sejumlah 2177 anggota, dan terdapat dua provinsi yang tidak memiliki kelompok BKR yaitu provinsi Kalimantan Utara dan Papua Barat, sedangkan di provinsi Papua jumlah kelompok BKR sebanyak 16 kelompok, namun tidak ada satupun kelompok yang aktif dalam kelompok BKR tersebut.

Sedangkan di Kota Batam jumlah kelompok BKR sejumlah 16 kelompok dan jumlah anggota BKR sebanyak 95 anggota. Salah satu kecamatan yang memiliki kelompok BKR terbanyak adalah kecamatan Batam Kota sebanyak 8 kelompok dengan jumlah 40 anggota. Dan terdapat 6 Kecamatan di Kota Batam yang belum mempunyai kelompok BKR yaitu seperti kecamatan Batu Ampar, Nongsa, Bulang, Galang, Sagulung dan Batu Aji. Hal ini dikarenakan Karena kurangnya pengetahuan keluarga mengenai program kerja dari BKKBN yaitu Bina Keluarga Remaja (BKR).

Berdasarkan rekomendasi dari Badan Pemberdayaan Perempuan, Perlindungan Anak dan KB Kota Batam bahwa penelitian akan dilakukan di Kampung Tua Dapur 12 Kelurahan Sei Pelunggut Kecamatan Sagulung dikarenakan lokasi tersebut merupakan salah satu daerah kerja dari Badan Pemberdayaan Perempuan, Perlindungan Anak dan KB Kota Batam dan BKKBN. Kampung Tua Dapur 12 Kelurahan Sei Pelunggut merupakan lokasi yang terkenal dengan sebutan kampung KB. Oleh sebab itu dengan rekomendasi dari institusi bersangkutan bahwa peneliti akan melakukan penelitian dilokasi tersebut. Dan hasil pra survey yang telah dilakukan pada hari sabtu tanggal 25 Maret 2017 di Kampung Tua Dapur 12 Kelurahan Sei Pelunggut Kecamatan Sagulung didapatkan kesimpulan banyaknya orang tua atau keluarga yang tidak mengetahui tentang tumbuh kembang remajanya.

Tujuan Penelitian ini adalah Diketahui perbedaan rerata sebelum dan sesudah pemberian informasi tentang Bina Keluarga Remaja di Kampung Tua Dapur 12.

\section{METODE}

Desain Penelitian Quasi eksperimental dengan rancangan pretest-posttest one group design adalah penelitian ini dilakukan sebanyak dua kali yaitu sebelum eksperimen (pretest) Responden diberikan kuesioner untuk mengetahui pengetahuan sebelum dan kemudian diberikan perlakuan berupa pembagian Leaflet dan Penyuluhan setelah itu dilakukkan (posttest) dengan satu kelompok subjek (Arikunto, 2010). Waktu penelitian ini dilakukan pada bulan Februari-Agustus 2017. Tempat penelitian ini dilakukan di Kampung Tua Dapur 12. Populasi dalam penelitian ini adalah keluarga yang memiliki remaja usia 10-24. Teknik pengambilan data menggunakan Total Sampling dimana keluarga yang memiliki remaja di Kampung Tua Dapur 12 Kelurahan Sei Pelunggut Kecamatan Sagulung Kota Batam Tahun 2017 yang berjumlah 147 orang. Instrumen pada penelitian ini menggunakan lembaran kuesioner. Alur penelitian dimulai dari mengumpulkan sample yaitu keluarga baik itu ayah atau ibu yang di berikan pretest dan selanjutnya diberikan perlakuan berupa penyuluhan kesehatan mengenai topic terkait dan diukur kembali mengunakan instrument yang sama untu melihat hasil post testnya, selanjutnya dilakukan pengolahan data secara Univariat dan Bivariat menggunakan Uji T-Test.

\section{HASIL DAN PEMBAHASAN}

Penelitian ini dilakukan di Kampung Tua Dapur 12 Kelurahan Sei Pelunggut Kecamatan Sagulung Kota Batam Tahun 2017. Sejak tahun 
1930 kawasan ini ditempati oleh orang melayu yang hidup sebagai nelayan. Namun dengan berakhirnya penjajahan jepang tahun 1946 tempat ini mulai di bangun oleh orang Tionghoa yang membuka usaha kayu arang dengan membangun dapur sebanyak 12 buah, dari sinilah nama Dapur 12 bermula. Secara umum wilayah Kelurahan Sei Pelunggut terdiri dari KSB dan Daerah Pinggiran / Pemukiman Lama. Luas wilayah Kelurahan Sei Pelunggut adalah : 5,2 $\mathrm{Km}^{2}$. Potensi daerah Sei Pelunggut adalah : pertanian, perikanan dan industri dengan jumlah Penduduk : 19.292 jiwa terdiri dari Laki -laki : 10.186 jiwa, dan Perempuan : 9.106 jiwa dengan sebanyak 70 RT dan 21 RW yang mayoritas beragama islam dan mayoritas bersuku bangsa Buton. Kelurahan Sei Peunggut memiliki beberapa sarana pendidikan yang terdiri dari 1 sekolah SD, 1 sekolah SLTP, dan 1 sekolah SLTA, selain itu Kelurahan Sei Pelunggut juga memiliki sarana kesehatan yang terdiri dari 1 puskesmas pembantu dan 1 posyandu, dan juga memiliki sarana olah raga yang terdiri dari 1 lapangan volly dan 1 lapangan sepak bola dan juga tersedianya tempat beribadah 1 musholllah.

Berdasarkan hasil wawancara tersebut dari kader BKR, maka dapat disimpulkan bahwa pelaksanaan program BKR yang dilakukan oleh Badan Pemberdayaan Perempuan dan Keluarga Berencana (BPPKB) di Kampung Tua Dapur 12 saat ini sudah berjalan, karena sudah terbentuk kelompok BKR namun pelaksanaan kegiatan dalam kelompok BKR tidak rutin dilakukan setiap bulan. Tentu saja, hasil laporannya tidak sesuai dengan harapan. Jumlah kelompok juga belum berkembang dan merata bila dibandingkan dengan jumlah keluarga yang mempunyai remaja di Kelurahan tersebut. Selain itu, Pembentukan kelompok juga harus dilakukan di setiap lingkungan agar tercipta suatu konseling keluarga yang dijadikan sebagai wadah untuk mendapatkan pemahaman dan sumber informasi bagi orang tua dalam mendidik anak remaja mereka dengan benar yang dilakukan dalam bentuk kelompok-kelompok kegiatan.

Dalam proses sosialisasi ini dapat disimpulkan bahwa kegiatan sosialisasi dalam program BKR tidak hanya dilakukan melalui pendekatan dan penyuluhan saja untuk lebih optimal maka proses sosialisasi juga perlu dibuat banner, spanduk, gambar maupun brosur. Sehingga penyebaran informasi ini dapat merata di setiap kalangan masyarakat. Tujuannya adalah agar masyarakat dapat lebih mengetahui tentang Program BKR yang telah dicanangkan oleh Pemerintah melalui Badan Kependudukan dan Keluarga Berencana Nasional (BKKBN) yang penyebarannya dilakukan di seluruh Indonesia. Untuk itu, diperlukan mitra kerja sama dan institusi masyarakat terkait dalam melakukan promosi dan pengembangan Bina Keluarga Remaja (BKR).

Penelitian ini dilakukan untuk mengetahui apakah ada perbedaan antara pengetahuan keluarga sebelum diberikan informasi dan sesudah pemberian informasi tentang Bina Keluarga Remaja di Kampung Tua Dapur 12 Kelurahan Sei Pelunggut Kecamatan Sagulung Kota Batam Tahun 2017. Penelitian ini dilakukan dengan membagikan kuesioner sebelum diberikan informasi tentang Pengaruh Pemberian Informasi Terhadap Pengetahuan Keluarga Tentang Bina Keluarga Remaja setelah diberikan kuesioner pertama responen diberikan informasi seputar Bina Keluarga Remaja selanjutnya responden diberikan kuesioner kedua yang isi pertanyaannya sama dengan kuesioner pertama. Data yang diperoleh disajikan dalam bentuk tabel, dari penelitian tersebut diperoleh hasil sebagai berikut :

\section{Tabel 1 Uji Normalitas Rata - Rata Pengetahuan Keluarga Sebelum dan Sesudah di Berikan Informasi}

\begin{tabular}{lccc}
\hline Variabel & $N$ & Rerata \pm SD & $P$ \\
\hline $\begin{array}{c}\text { Pengetahuan } \\
\text { Sebelum }\end{array}$ & 147 & $18,18 \pm 4,88$ & \\
\cline { 1 - 2 } $\begin{array}{c}\text { Pengetahuan } \\
\text { Sesudah }\end{array}$ & 147 & $22,50 \pm 4,46$ & 0,087 \\
\hline
\end{tabular}

Hasil uji Normalitas data yang dilakukan penelitian menggunakan metode KolmogravSmirnov didapatkan nilai $p>0,05$ yang berarti bahwa pengetahuan keluarga sebelum dan sesudah diberikan informasi yang di uji terdistribusi normal, dengan demikian dapat dilanjutkan dengan uji T-test.

Tabel 2 Rerata Responden Berdasarkan Pengetahuan Sebelum Pemberian Informasi Tentang Bina Keluarga Remaja

\begin{tabular}{|c|c|c|c|}
\hline Variabel & Rerata \pm SD & Min & Max \\
\hline $\begin{array}{c}\text { Pengetahuan } \\
\text { Sebelum }\end{array}$ & $18,18 \pm 4,88$ & 8 & 27 \\
\hline \multicolumn{4}{|c|}{$\begin{array}{c}\text { Tabel } 3 \text { Rerata Responden Berdasarkan } \\
\text { Pengetahuan Sesudah Pemberian Informasi } \\
\text { tentang Bina Keluarga Remaja }\end{array}$} \\
\hline Variabel & Rerata $\pm S D$ & Min & Max \\
\hline $\begin{array}{l}\text { Pengetahuan } \\
\text { Sesudah }\end{array}$ & $22,50 \pm 4,46$ & 11 & 30 \\
\hline
\end{tabular}


Terdapat skor rerata pengetahuan sebelum pemberian informasi tentang Bina Keluarga Remaja adalah 18,18 $\pm 4,88$.

Terdapat skor rerata pengetahuan sesudah pemberian informasi tentang Bina Keluarga Remaja adalah $22,50 \pm 4,46$.

\section{Tabel 4 Rerata Pengetahuan Keluarga Sebelum dan Sesudah Pemberian Informasi Tentang Bina Keluarga Remaja}

\begin{tabular}{c|c|c|c|c}
\hline Variabel & $\mathrm{N}$ & Rerata & SD & $P$ \\
\hline $\begin{array}{c}\text { Pengetahuan } \\
\text { Sebelum }\end{array}$ & 147 & 18,18 & 4,88 & \multirow{2}{*}{0,00} \\
\hline $\begin{array}{c}\text { Pengetahuan } \\
\text { Sesudah }\end{array}$ & 147 & 22,50 & 4,46 & \\
\hline
\end{tabular}

Terdapat skor rerata pengetahuan sebelum pemberian informasi adalah 18,18 dan sesudah 22,50 , sehingga mengalami peningkatan sebesar 4,32. Hasil analisis lebih lanjut didapatkan nilai $p$ $0,000(p<0,05)$ yang berarti bahwa ada perbedaan yang signifikan skor rerata pengetahuan sebelum dan sesudah pemberian informasi.

Dari hasil penelitian terdapat skor rerata pengetahuan sebelum pemberian informasi tentang Bina Keluarga Remaja adalah 18,18 dan skor ratarata pengetahuan sesudah pemberian informasi tentang Bina Keluarga Remaja 22,50 sehingga mengalami peningkatan pengetahuan 4,32. Hasil analisis lebih lanjut didapatkan nilai $p$-value 0,000 (p $<0,05$ ) yang berarti bahwa ada perbedaan signifikan rerata pengetahuan sebelum dan pengetahuan sesudah pemberian informasi. Dapat disimpulkan bahwa ada pengaruh pemberian informasi terhadap pengetahuan keluarga yang memiliki remaja tentang Bina Keluarga Remaja di Kampung Tua Dapur 12.

Dari hasil penelitian ini peningkatan pengetahuan dikarenakan penyuluhan yang dilakukan peneliti untuk memberikan informasi mengenai Bina Keluarga Remaja. Hal ini sejalan dengan teori Notoadmodjo (2010), Pengetahuan merupakan hasil tidak tahu menjadi tahu, terjadi setelah orang melakukan penginderaan melalui pancaindera yang sebagian besar didapatkan melalui mata dan telinga, informasi bisa didaptkan melalui iklan media masa atau pun dilakukan penyuluhan seperti yang telah peneliti lakukan.(Notoatmodjo, 2012)

Pengetahuan seseorang biasanya diperoleh dari pengalaman yang berasal dari berbagai macam sumber, misalnya media massa, media elektronik, buku petunjuk, petugas kesehatan, media poster, kerabat dekat dan sebagainya. Pengetahuan ini dapat membantu keyakinan tertentu sehingga seseorang berprilaku sesuai keyakinan tersebut (Nandra, 2015)

Penelitian ini sejalan dengan penelitian terdahulu yang berjudul Efektivitas Program Bina Keluarga Remaja Dalam Upaya Pendewasaan Usia Pernikahan. Hasil penelitian menunjukan ada peningkatan informasi Upaya Pendewasaan Usia Pernikahan di Desa Karang Anyar dilhat dari hasil perhitungan sebesar $70,4 \%$. Hal ini sesuai dengan penelitian yang sedang peneliti lakukan, bahwa setelah peneliti memberikan informasi tentang Bina Keluarga Remaja terdapat peningkatan dikarenakan keluarga sudah mengerti tentang manfaat dan penerapan Bina Keluarga Remaja yang benar.(AGNES IBTINIA DISKA, 2016)

Media komunikasi adalah suatu sarana komunikasi bisa berupa alat atau sarana yang digunakan komunikator dalam menyampaikan informasi atau pesan kepada orang banyak. Media komunikasi manusia adalah pancaindera khususnya mata dan telinga. Fungsi media komunikasi adalah untuk kita melihat, menafsirkan, memahami sesuatu informasi yang ada disekitar kita $(A z, 2016)$

Dari hasil penelitian ini dikarenakan sudah adanya program BKR tersebut namun pelaksanaan kegiatan dalam kelompok BKR tidak rutin dilakukan setiap bulan, hal ini disebabkan karena Sumber Daya Pelaksana yang terbatas dan tingkat kemampuan petugas yang berbeda-beda dalam menyesuaikan diri dengan kondisi dan karakteristik masyarakat sehingga menjadikan program BKR belum optimal dilakukan dan hal inilah yang menyebabkan pengetahuan kader dan anggota BKR belum meningkat dan Kader BKR juga merasa kurang puas dengan kegiatan BKR ini sehingga menyebabkan mereka menjadi kurang aktif dan masih kurangnya minat keluarga untuk mencari informasi secara mandiri sehingga manfaat dan penerapan Bina Keluarga Remaja tidak diketahui oleh responden. Hal ini sejalan dengan teori, yang menyatakan bahwa minat adalah suatu kecendrungan atau keinginan yang tinggi terhadap sesuatu, minat menjadikan seseorang untuk mencoba sesuatu hal dan pada akhirnya diperoleh pengetahuan dan pengalaman.(Mubarak, 2007)

Keluarga merupakan lembaga pertama dalam kehidupan, tempat anak belajar dan berperan sebagai makhluk sosial. Keluarga juga merupakan satu-satunya lembaga sosial yang diberikan tanggung jawab untuk mengubah suatu organisme biologis menjadi manusia. Dalam keluarga umumnya anak melakukan interaksi yang intim. Pada saat sebuah lembaga mulai membentuk 
kepribadian seseorang dalam hal-hal penting, keluarganya tentu lebih banyak berperan dalam persoalan perubahan itu, dengan mengajarkan berbagai kemampuan dan menjalankan banyak fungsi-fungsi sosialnya (BKKBN, 2015).

$\mathrm{Hal}$ ini sejalan dengan penelitian terdahulu tentang Motivasi Orang Tua yang Memiliki Remaja Putri dan Keikutsertaan dalam Mengikuti Bina Keluarga Remaja di Kelurahan Kraton Lor kecamatan Pekalongan Utara Kota Pekalongan, dari penelitian tersebut yang mempengaruhi pengetahuan adalah keluarga yang mempunyai motivasi rendah untuk mengikuti kegiatan Bina Keluarga Remaja sehingga keluarga kurang mendapatakan informasi tentang pertumbuhan dan perkembangan remaja yang bermanfaat bagi keluarga. (Nina Zuhana, Nur Chabibah, 2016)

Dari hasil penelitian tersebut didapatkan bahwa ada pengaruh yang remaja di Kampung Tua Dapur 12 Kota Batam. Hal ini sejalan dengan teori (Notoatmodjo, 2012), menyatakan bahwa pengetahuan seseorang dipengaruhi beberapa faktor salah satunya informasi, informai yang menjadi perantara dalam meyampaikan informasi baik dari media cetak ataupun melalui tenaga kesehatan seperti pelatihan dan penyuluhan. Media yang digunakan peneliti adalah penyuluhan.

Hal ini sesuai dengan penelitian yang dilakukan oleh restu dan neneng tentang Peranan Kader Bina Keluarga Remaja dalam Menanggulangi Kenakalan Remaja di Desa Margahayu Selatan, Kecamatan Margahayu, Kabupaten Bandung, dimana penelitian tersebut menunjukan adanya peningkatan keterampilan yang signifikan sebelum dan sesudah diberikan penyuluhan BKR serta pelaksanaan program BKR. (Tripuspita \& Ginanjar, 2014) Penelitian ini sama-sama terdapat pengaruh peningkatan setelah di lakukan penyuluhan dan pelaksanan program BKR yang dimana sama-sama menambah informasi bagi responden tersebut sehingga pengetahuan menjadi meningkat,

Pemberian Informasi sangat berguna bagi pengetahuan seseorang ini juga didukung dari hasil penelitian dengan judul "Peran Penyuluh Lapangan Keluarga Berencana Melalui Program Bina Keluarga Remaja Dalam Mengatasi Kenakalan Remaja Di Desa Mangunsari Kecamatan Gunungpati Kota Semarang " yaitu terdapat Faktor pendukung dan penghambat pelaksanaan kegiatan bina keluarga remaja di Mangunsari. Faktor pendukung antara lain peserta kegiatan antusias dalam mengikuti kegiatan Bina Keluarga Remaja, pemerintah setempat sangat mendukung kegiatan Bina Keluarga Remaja. Sedangkan kendalanya adalah masalah sarana prasarana terutama masalah dana yang tidak ada sehingga kader Bina Keluarga Remaja iuran dan masalah tempat kegiatan yang belum ada, selain itu belum ada motivasi intrinsik dari peserta kegiatan (Nur, 2017)

Penelitian dengan Judul Pengaruh penyuluhan bina keluarga remaja terhadap pola asuh demokratis : Penelitian pada orang tua dalam program bina keluarga remaja di kelurahan Pasir Biru kecamatan Cibiru Bandung Hasil penelitian menunjukkan bahwa pelaksanaan penyuluhan bina keluarga remaja terdiri dari tahapan permulaan (pemanasan dan pembukaan), tahapan pembahasan materi yang lalu, tahapan materi pokok dan tahapan penutup dengan menggunakan metode langsung ataupun kunjungan rumah serta media penunjang yaitu media audio-visual dan visual. Selanjutnya, pengaruh penyuluhan bina keluarga remaja terhadap demokratis hasilnya dikategorikan kuat karena menujukan persentase sebesar 63 persen sisanya sebesar 37 persen Maksudnya, selain dari penyuluhan, pola asuh demokratis dipengaruhi oleh variabel lain (Katili, 2018)

Penelitian dengan Pengembangan Keterpaduan Bina Keluarga Remaja Dan Pusat Informasi Konseling Remaja Di Wilayah Perdesaan Dan Perkotaan Daerah Istimewa Yogyakarta dan Hasil penelitian: (1) Wilayah perdesaan, layanan BKR berupa pertemuan penyuluhan, kunjungan rumah, pemantauan permasalahan remaja; sedangkan layanan PIK $R$ berupa pertemuan penyuluhan. Wilayah perkotaan layanan BKR berupa pertemuan penyuluhan, kunjungan rumah, rujukan, pemantauan permasalahan remaja, layanan PIK R berupa pertemuan penyuluhan, (2) terdapat faktor internal dan eksternal yang berpengaruh dalam pemanfaatan layanan PIK R. (3) Kegiatan sosial kemasyarakatan remaja: olahraga, kesenian, keagamaan, karang taruna. (4) Sinergisitas BKR dan PIK R belum optimal. (5) Hasil Model Pengembangan Keterpaduan berupa Pelayanan terpadu, Integrasi layanan dengan kegiatan sosial kemasyarakatan, Penjadwalan pertemuan, Penambahan dan pengembangan materi. (6) Modul pengembangan keterpaduan diupayakan dengan membuat buku saku (Nurul Khotimah, Anik Ghufron, Kanthi Aryekti, 2017)

Dari uraian tersebut dapat disimpulkan bahwa informasi yang diterima melalui penyuluhan ini meningkatkan pengetahuan keluarga di Kampung Tua Dapur 12 Kelurahan Sei Pelunggut Kecamatan Sagulung Kota Batam. Hal ini dikarenakan dari faktor yang mempengaruhi keluarga seperti pemberian informasi yang diberikan kepada keluarga sehingga pengetahuan 
keluarga tentang Bina Keluarga Remaja menjadi lebih baik, penelitian ini adalah pengetahuan keluarga mengalami peningkatan setelah dilakukan pemberian informasi, yaitu dengan nilai rerata 22,50 \pm SD 4,46. Pengetahuan sebelum diberikan informasi cukup. Hal ini disebabkan kurangnya minat keluarga untuk mencari informasi tentang Bina Keluarga Remaja. Dan informasi yang diterima melalui penyuluhan ini meningkatkan pengetahuan keluarga di Kampung Tua Dapur 12 Kelurahan Sei Pelunggut Kecamatan Sagulung Kota Batam. Hal ini dikarenakan dari faktor yang mempengaruhi keluarga seperti pemberian informasi yang diberikan kepada keluarga sehingga pengetahuan keluarga tentang Bina Keluarga Remaja menjadi lebih baik. Hal ini menunjukan bahwa pengetahuan seseorang bisa didapatkan dari sumber informasi seperti media cetak, media elektronik maupun media massa seperti penyuluhan.

\section{SIMPULAN}

Berdasarkan penelitian yang dilakukan di Kampung Tua Dapur 12 Kota Batam tentang Pengaruh Pemberian Informasi Terhadap Pengetahuan Keluarga Tentang Bina Keluarga Remaja sebanyak 147 responden. Hasil yang didapatkan pada penelitian :

Ada perbedaan signifikan skor rerata pengetahuan keluarga sebelum diberikan informasi adalah 18,18 dengan sudah diberikan informasi adalah 22,50 sehingga mengalami peningkatan sebesar 4,32.

Rekomendasi bagi peneliti selanjutnya dapat mengembangkan hasil karya tulis ilmiah ini dengan menggunakan metode selain yang digunakan penelitian ini. Misalnya hubungan pengetahuan dan sikap keluarga tentang Bina Keluarga Remaja.

\section{SARAN}

Bagi Petugas Kesehatan Penelitian ini diharapkan dapat dijadikan sebagai bahan informasi dalam upaya meningkatkan Pengetahuan Keluarga, khususnya Bina Keluarga Remaja.

\section{UCAPAN TERIMA KASIH}

Dalam kesempatan ini penulis mengucapkan terima kasih kepada LPPM Universitas Batam yang telah memberikan kesempatan dan semangat bagi penulis untuk terus melakukan penelitian guna terlaksananya Tugas Tri Dharma Perguruan Tinggi.

\section{KEPUSTAKAAN}

AGNES IBTINIA DISKA. (2016). EFEKTIVITAS PROGRAM BINA KELUARGA REMAJA DALAM UPAYA PENDEWASAAN USIA
PERNIKAHAN. BANDAR LAMPUNG.

Arikunto. (2010). Prosedur Penelitian: Suatu Pendekatan Praktek. Jakarta: Rineka Cipta.

Az. (2016). Pengertian Media Komunikasi :Fungsi dan Macam Macamnya. Retrieved from http://artikel-az.com/pengertian-mediakomunikasi

BAPPENAS, BPS, U. (2013). Proyeksi Penduduk Indonesia 2010 - 2035. Jakarta.

BKKBN. (2013). Bina Keluarga - Integrasi Aplikasi BkkbN. Retrieved March 31, 2017, from http://aplikasi.bkkbn.go.id/bkr/Report/Lapor anProgresBKR.aspx

BKKBN. (2015). Delapan Fungsi Keluarga. Jakarta.

Katili, F. L. (2018). Pengaruh penyuluhan bina keluarga remaja terhadap pola asuh demokratis: Penelitian pada orang tua dalam program bina keluarga remaja di kelurahan Pasir Biru kecamatan Cibiru Bandung. UIN Sunan Gunung Jati. Retrieved from http://digilib.uinsgd.ac.id/10248/

Kemenkes, R. (2016). Situasi Kesehatan Reproduksi Remaja. Jakarta Selatan.

Mubarak. (2007). Promosi Kesehatan Sebuah Pengamatan Proses Belajar Mengajar dalam Pendidikan. Yogyakarta: Graha IImu.

Nandra. (2015). Konsep Pengetahuan. Retrieved from

https://tintahmerah.wordpress.com/2015/06 /23/konsep-pengetahuan

Nina Zuhana, Nur Chabibah, N. A. K. (2016). Motivasi Orang Tua yang Memiliki Remaja Putri dan Keikutsertaan dalam Mengikuti Bina Keluarga Remaja. Jurnal IImiah Kesehatan (JIK), IX. Retrieved from https://media.neliti.com/media/publications/ 97229-ID-motivasi-orang-tua-yangmemiliki-remaja.pdf

Notoatmodjo, S. (2012). Pendidikan dan Perilaku Kesehatan. Jakarta: Rineka Cipta.

Nur, H. R. (2017). Peran Penyuluh Lapangan Keluarga Berencana Melalui Program Bina Keluarga Remaja Dalam Mengatasi Kenakalan Remaja Di Desa Mangunsari Kecamatan Gunungpati Kota Semarang. Semarang. Retrieved from http://lib.unnes.ac.id/31143/1/1201413081. pdf

Nurul Khotimah, Anik Ghufron, Kanthi Aryekti, S. S. (2017). Pengembangan Keterpaduan Bina Keluarga Remaja Dan Pusat Informasi Konseling Remaja Di Wilayah Perdesaan 
Dan Perkotaan Daerah Istimewa Yogyakarta. GeoMedia, Vol 15, No. Retrieved from https://journal.uny.ac.id/index.php/geomedi a/article/view/16233

Tripuspita, N., \& Ginanjar, R. S. P. (2014). PERANAN KADER BINA KELUARGA REMAJA DALAM MENANGGULANGI KENAKALAN REMAJA (Studi Deskriptif
Pada Bina Keluarga Remaja Anggrek 11 Di Desa Margahayu Selatan Kecamatan Margahayu Kabupaten Bandung). Jurnal Pendidikan Hukum, Pancasila, Dan Kewarganegaraan, 1, 181-192. Retrieved from https://ppknstkippasundan.files. wordpress.com/2015/06/7-restu-danneneng-tripuspita.pdf

WHO. (2013). Reproductive Health. 